\title{
COMMUNICATIONAL TIES BETWEEN THE REPUBLIC OF BASHKORTOSTAN AND OTHER RUSSIAN REGIONS BASED ON VOICE CELL PHONE DATA
}

\author{
Valeriy V. Yumaguzin ${ }^{1}$, Maria V. Vinnik' \\ ${ }^{1}$ National Research University Higher School of Economics (HSE), Moscow, Russia. \\ *Corresponding author: vyumaguzin@hse.ru \\ Received: May 24 $4^{\text {th }}, 2020$ / Accepted: August 9 ${ }^{\text {th }}, 2020$ / Published: October $1^{\text {st }}, 2020$ \\ https://DOI-10.24057/2071-9388-2020-98
}

\begin{abstract}
The article aims to present social ties of the Republic of Bashkortostan based on voice cell phone data, which covers 12 million calls from and to the region during the first five days of March 2020. About 96\% of calls are made within the republic and only 4\% of them are interregional. The people of the Republic of Bashkortostan have close connections with those who live in neighboring regions (Orenburg, Sverdlovsk oblast, the Republic of Tatarstan and especially Chelyabinsk oblast). Being a part of the Ural Economic Region, the Volga Federal District and Volga-Ural Macro Region, the republic has turned mostly towards Ural regions. We also found that the republic has close social ties with Moscow and Moscow region, St. Petersburg and Leningrad oblast, as well as Krasnodar kray, Samara oblast and two Autonomous Districts: Khanty-Mansi and Yamalo-Nenets. We estimated the number of persons who possessed Bashkir SIM-card and were outside the republic during the research period - 183 thousand; the most of them were in the abovementioned regions. While conversation between residents lasts 50 seconds, which is among the smallest values, the calls to and from republics of Altai, Tyva, Khakassia, Sakha and Magadan oblast are 5-8 times longer. Overall, the communication pattern reflects migration flows and economic relations between regions. The results of this study can be utilized by researchers and Bashkir government to explore spatial interaction patterns between regions and may help to guide transportation planning and other potential applications, e.g. infrastructure construction projects. In conclusion, we postulate that cell phone data can be exploited as a source of social ties data, however, the strengthening communication shift into Internet space is diminishing information on the directional features of the ties.
\end{abstract}

KEY WORDS: cell phone data, social ties, Bashkortostan, Chelyabinsk oblast, migration, communication, digital demography, regional relations, Ural Economic Region

CITATION: Valeriy V. Yumaguzin, Maria V.Vinnik (2020). Communicational ties between the Republic of Bashkortostan and other Russian regions based on voice cell phone data. Geography, Environment, Sustainability, Vol.13, No 4, p. 133-139 https://DOI-10.24057/2071-9388-2020-98

ACKNOWLEDGEMENTS: This article is an output of a research project implemented as part of the Basic Research Program at the National Research University Higher School of Economics (HSE)

Conflict of interests: The authors reported no potential conflict of interest.

\section{INTRODUCTION}

Russia is the largest country in the world and has the highest number of subjects among federative states (85 against 51 in the USA, 27 in Brazil, 16 in Germany, 13 in Canada) (Russian regions, 2011). In this regard, spatial and socio-economic development policy of the country at a regional level is of particular interest due to diversity of the regions. The Russian school of socio-economic zoning, founded by N. N. Baranskiy in the late 1920s, remains relevant to this day (there are 12 Economic Regions in Russia). The division of the country into 8 Federal Districts has changed the grouping of the regions. These territorial units were created artificially solely for the convenience of management and do not have a deep socio-economic basis, so geographers and economists continue to compare the situation of each region, with the regions within the same Economic region, although State Statistics are often aggregated at the level of Federal districts, which somewhat complicates interregional studies. According to the "Strategy of spatial development of the Russian Federation for the period up to 2025», adopted in February 2019, and developed by the Ministry of economic development of the Russian Federation, the country is again divided into 12 Macro-Regions, but with a different composition of subjects than before.

The Republic of Bashkortostan is a part of the Ural Economic Region, the Volga Federal District and Volga-Ural Macro-Region.

There are other regional classifications as well, that do not take into account the territorial features of the location. L. M. Grigoriev, Y. V. Urazhaeva, D. S. Ivanov proposed classification based on the stage of development and industrial structure of the regions (Russian regions 2011). According to them, the Republic of Bashkortostan along with Krasnoyarsk and Perm kray, Belgorod, Kemerovo, Murmansk and Tomsk oblast were included into the group of developed regions with mainly extractive industry. 
Among the indicators that are used to build classifications are GRP and income of the population, characteristics of the sectoral structure of the economy, the situation on the labor market, demographic and infrastructure indicators. However, the output does not necessarily reflect the regional cohesion.

The Republic of Bashkortostan connects the European and Asian parts of Russia through Federal Highways (M5 «Ural» and M7 «Volga») and railroads. Being an ethnic republic it has a high share of Bashkirs (29.5\%) and Tatars (25.4\%), however, Russians are well integrated as well with their share of $36 \%$ in total population. According to Census 2010 data, $83 \%$ of people who were born in the Republic of Bashkortostan lived in the region; other $17 \%$ lived outside the region. From the perspective of the present population, $87,6 \%$ of those who lived the republic were born in the republic, 6,7\% were born in other Russian regions and $5,7 \%$ had foreign origin. Of those who lived in other Russian regions, 9,8\% have moved to their current location within the Republic of Bashkortostan during the last 12 months (Volume 8, 2020). In the interregional migration the republic steadily loses more migrants than gains since the beginning of 2000-s, the migration decline in 2007-2018 has reached 80 thousands persons (Population migration, 2020). In addition, in 2017, the republic was in the top-15 Russian regions with the highest rates of internal labor migration, ranked $3^{\text {rd }}$ place by the number of such migrants and $13^{\text {th }}$ place by the share of migrants in employed population, which were working in other region (Khilazheva 2019). It is estimated that among those who were working out of their communities, $64,5 \%$ of men and $38,6 \%$ of women used to work outside the republic and the rest - within the republic (Khilazheva 2017).

To date, regional connections have been estimated by measuring physical and economic distances, migration flows and goods turnover. Based on innovative digital data - social media and mobile phone, - researchers are able to introduce and assess social ties. However, we are aware of only few foreign studies that have utilized mobile phone data to measure communicational ties and regional cohesion (Blumenstock 2011; Gao et al. 2013). Indeed, a novel digital source of data may be very useful in the analysis as it becomes increasingly involved in socio-demographical and geographical studies (Inferring, 2016; Makhrova et al 2017; Zamyatina, Yashunskij 2018; Yumaguzin, Vinnik 2019). For example, Yumaguzin (2017) applied mobile phone data in accessing a pendulum migration in Ufa, Republic of Bashkortostan. The research was attempted to follow the migration routes through location-based information of people who made calls regardless of their direction. The current research studies direction and duration of the calls. To the best of our knowledge, this is the first effort to reveal interregional communicational patterns based on cell phone data in Russia.

It is time to say, that in 2018, the number of SIM-cards used in Russia amounted to more than 255 million, the level of penetration of cellular services (the number of SIM-cards per person), according to mobile operators, amounted to $179 \%$. The highest level of penetration was observed in Moscow (249\%) and St. Petersburg (248\%). In other regions the average level of penetration was 164\%". According to this indicator, Russia is among the most developed telecommunication markets in the world. At the same time, the actual level of penetration of cellular services in the mid-2010s was estimated at 75\%-79\%
(Zubarev, Perevoznikova, 2015). For comparison, the level of penetration of social networks in Russia in the same period was only 33\% (Inferring, 2016). That is, the results of data analysis of mobile operators are likely to be more reliable due to the lower selectivity of service users.

The aim of the paper is to present social ties of the Republic of Bashkortostan based on voice cell phone data. It is a pilot study of the project intended to explore «The regional cohesion in Russia».

\section{The paper examines three hypotheses:}

1. Communicational ties between first-order neighbor regions are higher than with second-order neighbors and so on.

2. Being a Muslim region with a high share of Tatars, the Republic of Bashkortostan has the strongest social connection with the Republic of Tatarstan, which is also more economically developed than the Republic of Bashkortostan and more attractive for migrants.

3. The hypertrophied role of Moscow is manifested not only in economic and demographic interaction with the regions, but also in social communication.

\section{DATA AND METHODS}

Our research is based on the fine-grained data of one of the three major companies that covers a third of the whole Russian population. The data includes the number and duration of cellphone calls, which were made or received by the residents of the Republic of Bashkortostan during 1/03-5/03/2020 per 2 hour period. Personal and business accounts are combined. About six millions calls were made in each direction; however, the vast majority of them (96\%) belonged to intra-regional calls. We compute the following statistics based on the mobile phone voice transaction history: the amount of inbound and outbound calls, their median and average length, the regional direction of the calls in relation to the Republic of Bashkortostan. We used these parameters in the K-means clustering to build a map and graphs of the social ties of the Republic of Bashkortostan.

Cell phone data has its own limitations. The sample does not represent all the population of the republic, because there may be differences between people who own mobile phones and people who do not own mobile phones. In addition, our sample is restricted by persons who are using the mobile voice call data and do not include those, who communicate exceptionally via SMS, Internet or landline. According to our mobile data, on average $92 \%$ of all active SIM-cards are used for making or receiving voice calls (in different combinations with SMS and Internet), ranging from 84\% to 95\% in Russian regions, the rest of the SIM-cards are used solely for SMS or Internet communication. Furthermore, we are unable to observe and track voice calls that are represented by the other two main operators in the republic.

Though we are exploiting the voice calls made in home regions, i.e. by residents, there is a chance that some proportion of people buy local SIM-cards while travelling in other regions to minimize their communication costs through making local calls and calling to their home region. However, elimination of the interregional roaming in August 2018 in Russia, should have led to the demise of such practices, because communication in a guest region with a person's own SIM-card is not extra charged at a premium anymore. 
The cost of interregional calls may depend on tariff plan options, which may encourage or restrain interregional communication between persons. Obviously, we cannot grasp calls made by Skype, WhatsApp and other applications via the Internet, that probably are more common among the youth, and persons for whom the price of mobile calls is expensive.

There are no data on the Republic of Crimea and its capital Sevastopol. Data on Nenets Autonomous Okrug comes with the Arkhangelsk oblast. Data on the Republic of Adygeya is combined with the Krasnodar krai. Data on the Moscow oblast and Moscow are also combined, as well as data on St. Petersburg and the Leningrad oblast. We own data on a total of 79 regions. Maps and graphs are created in GeoDa 1.14.0.24 and Gephi 0.9.2 respectively.

Despite these limitations, it is also important to point out that by using cell phone data, we have been able to depict the regional cohesion.

\section{RESULTS}

Based on voice mobile traffic data of the cell phone operator, which covers calls from and to the Republic of Bashkortostan, we built a map of main interlocutors of this region (Fig. 1). The main clusters are - (1) Chelyabinsk oblast, (2) Sverdlovsk, Orenburg oblast and the Republic of Tatarstan, (3) Moscow and Moscow region, (4) the Republic of Bashkortostan itself, (5) Krasnodar kray, Khanty-Mansi Autonomous District (AD) - Yugra, Yamalo-Nenets AD, Samara oblast, St. Petersburg and the Leningrad oblast; and the last cluster (6) is the rest of the regions. Overall, the people of the Republic of Bashkortostan have close connections with those who live in neighboring regions. Comparing the regional composition of the Ural Economic Region, the Volga Federal District and Volga-Ural Macro Region, we can prove that the population of the republic has turned toward Ural regions.

The figure 2 shows inbound and outbound calls in the Republic of Bashkortostan. The highest number of calls are made within the republic; for illustrative purposes, we decreased this number by 80 times. Among other regions, the largest number of calls are received from and made to Chelyabinsk oblast, followed by Moscow and Moscow region, the Republic of Tatarstan, Sverdlovsk oblast and Orenburg oblast. The amount of total talk hours almost corresponds to this ranking; however, the Orenburg oblast is shifted down by Saint-Petersburg and the Leningrad oblast in the ranking of incoming calls; Sverdlovsk oblast and Orenburg oblast switched places in the ranking of outcoming calls. In terms of median duration of the calls, the picture is totally different. The conversation between residents lasts 50 seconds, which is among the smallest values, whereas the longest conversations with people of the Republic of Bashkortostan are induced by residents of the Republic of Khakassia, Magadan oblast, the republics of Sakha and North Ossetia. The median duration of the calls in these cases are more than 5 minutes. In turn, the people of the Republic of Bashkortostan preferred to have long talks with those who live in such republics as Altai, Tyva and Khakassia - the median is 4-5 minutes.

\section{DISCUSSION}

In this paper, we provided for the first time (to the best of our knowledge) a snapshot of the social ties between some Russian regions based on voice calls data and identified regional clusters with close social connections. While discussing our findings, we will validate them with both digital and traditional data, such as social media data, migration statistics and economic turnover data. This will allow us to acclaim that cell phone data can be used as a source of social ties data.

E.G. Ravenstein postulated the importance of the first order regions in migration, and now it is a well-known law in regional studies, however widely available means of communication may distort the pattern at different regional scales. That is why it must be tested firstly. As we poses data on the level of Russian regions, we can infer some conclusions at this level, however further work at the community, country and international levels is required in the future. For now, we have found empirical evidence of the importance of the first order neighboring regions in social communication. Chelyabinsk oblast is truly a sister region of the Republic of Bashkortostan. In fact, the Bashkir Far Ural («Zaural'e») territories and towns (Sibay, Uchaly, Baimak and Beloretsk) tend to cooperate with developed

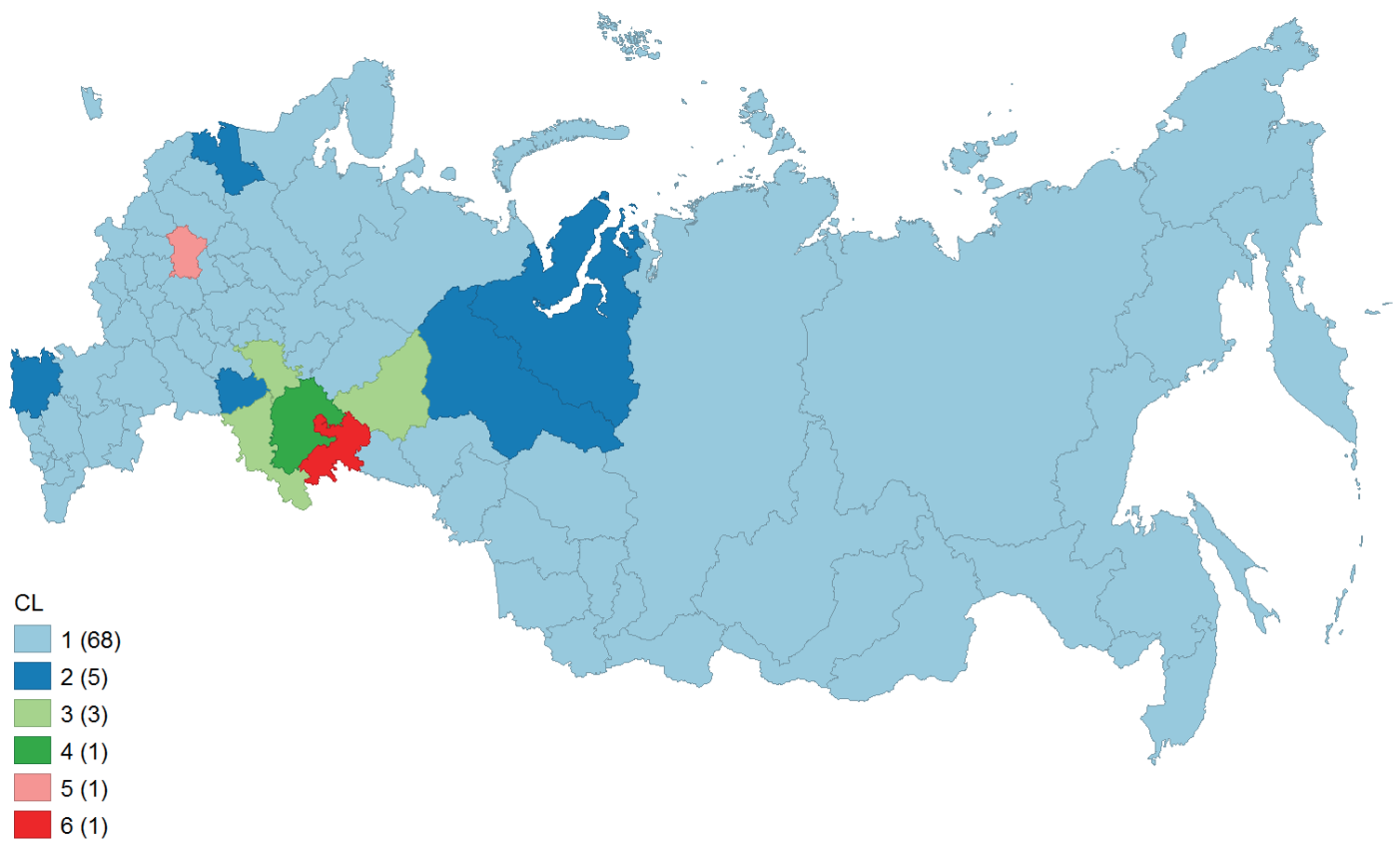

Fig. 1. Clustering of the social ties of the Republic of Bashkortostan

Note: there are six clusters with the number of regions in the brackets. 

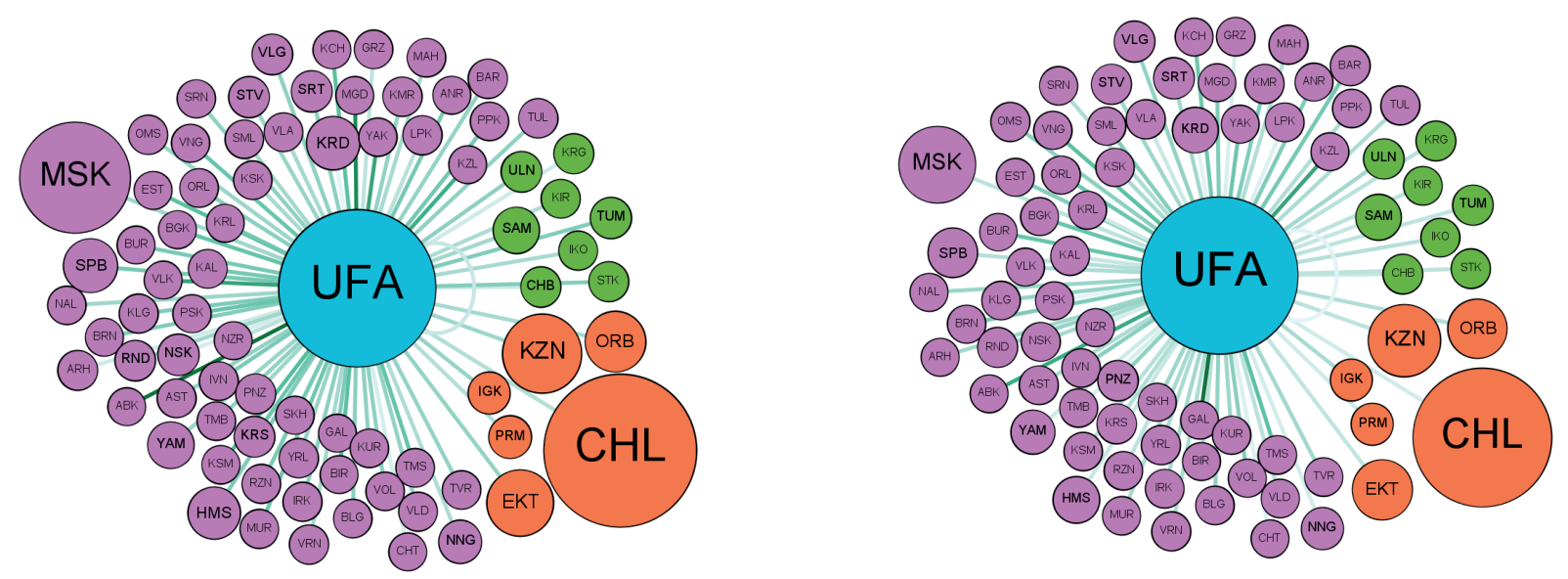

Fig. 2. Inbound (left) and outbound (right) calls in the Republic of Bashkortostan

Note: The size of the nodes corresponds to the number of calls, the color of the nodes represents the border order in relation to the republic (orange $-1^{\text {st }}$ order region, green $-2^{\text {nd }}$ order region, magenta $-3^{\text {rd }}$ order and higher, blue is the Republic of Bashkortostan itself), the color of the edges corresponds to the median duration of the calls. The list of the regions is provided in Appendix.

cities of Magnitogorsk and Chelyabinsk, which are close to the East Bashkir border. On the other hand, the Bashkir capital, Ufa, may attract citizens of Magnitogorsk and Chelyabinsk that forms reverse flows of people. K-means clustering has revealed a huge role of the Moscow region and St. Petersburg as well, depicting the first as a separate cluster (figure 1). Khanty-Mansi AD - Yugra is a second order neighbor region. However, being an oil-producing region it draws in specialists from different regions, especially those that have petroleum technological universities. One of them is located in Ufa; the Ufa State Petroleum Technological University also has three branches, which are in the cities of Oktyabrsky, Salavat and Sterlitamak. The same explanation works for Yamalo-Nenets AD as well.

Both Samara oblast and Krasnodar kray play significant roles in communicational relationships with the republic, they took place in a same cluster with two mentioned autonomous districts, St. Petersburg and the Leningrad oblast. Samara oblast is a second order region neighbor that also has refineries. In addition, the region has leading universities (Ataeva, Ulyaeva 2018), higher wages (Khilazheva et al. 2017) and locates in the European part of Russia so it can serve both as educational center and as a destination point in the «Western drift», including for migrants from Ural regions. Although people of Volga regions themselves started to resettle closer to the Russian capital. Being a regional center of attractiveness for migrants before 2012, Samara oblast has since begun to lose its population showing the negative rates of interregional migration (Population of Russia 2018).

In contrast, Krasnodar kray is a huge region, which along with Moscow and St. Petersburg, belongs to the centers of attraction for migrants throughout the last three decades (Population of Russia 2018), due to the economic development, low unemployment rates and a high level of housing construction. The population of the capital of the region, Krasnodar, has increased by 200 thousands people in the last two decades; now its population is close to 1 million citizens. The city had the highest rate of migration increase among federal cities and regional capitals between 2006-2016 (Population of Russia 2018).

The number of calls from Moscow and Moscow region as well as from Krasnodar kray is 2 times higher than reverse calls. The number of calls from Archangelsk oblast exceeds the number of calls to this region by five times, the same ratio for Novosibirsk oblast equals almost 3. As our data contains both individuals and entities, uneven density of call-centers, marketing and other communication services in the regions may distort the overall picture. Another explanation is that the price of interregional calls is more affordable for these residents; however, it can be captured only on individual-level data.

According to our data, there are 61 thousand people who possessed Bashkir SIM-card and were outside the republic during the research period, which gives roughly $183\left(61^{*} 3\right)$ thousand persons totally with the assumption of equal distribution of other two cell phone operators in the republic (Yumaguzin 2017). The value is very close to the Rosstat data on labour migrants from the republic of Bashkortostan, who were employed outside of the region, which is 161.8 thousand persons in 2018 with the upward trend in the last six years (Distribution 2020). About 26\% of cell phone users were in Chelyabinsk oblast, 12\% - in Moscow and Moscow region, 10\% - in the Republic of Tatarstan, 6\% - in the Republic of Chechnya, 5\% - in Sverdlovsk oblast. Yamalo-Nenets AD, Orenburg oblast and the Republic of Dagestan each attracted $4 \%$ of Bashkir tourists/residents, St. Petersburg and the Leningrad oblast had 3\% of Bashkir citizens, Krasnodar kray, Khanty-Mansi AD - Yugra and Samara region each had about 2\%. We must highlight here again, that this is actually not the persons themselves, but the distribution of the SIM-cards, which were bought in the republic, and subscribers may own more than one cell phone. On the other hand, as we said earlier, the elimination of the national and interregional roaming have led to the practice when people continue to use their SIM-cards outside their home region and do not buy local ones, even when they plan to stay at the new place for a longer period and probably become residents of that place. Another aspect is that the calls may be made while travelling, so the location does not necessarily coincide with the destination region.

Zamyatina and Yashunskij (2018) presented migration flows and friendship between users' cities and regions based on Russian social network «VK». They found that the regions of the Ural Economic Region have multidirectional migration flows. Huge flows of users interconnect the Republic of Bashkortostan and Chelyabinsk oblast. In addition, there are one-way flows to the Republic of Tatarstan and Khanty-Mansi AD - Yugra from the Republic of Bashkortostan, among the 30 the largest migration flows between Russian regions, excluding Moscow and St. Petersburg. The interregional friendship maps (Virtual 2020) shows that Bashkir users have friends mostly in 
Khanty-Mansi AD - Yugra, Yamalo-Nenets AD, Chelyabinsk oblast, the Republic of Tatarstan, Orenburg oblast, Amur oblast, Penza oblast, the Udmurt Republic and Sverdlovsk oblast. Overall, based on social media data, we can confirm that first order border regions of the Republic of Bashkortostan have higher connectivity with it.

While analyzing the conducted research on «Demographic development of the Republic of Bashkortostan», Khilazheva (2015) writes that 3,4\% of the sample $(n=1000)$ were intended to move from the Republic of Bashkortostan to other Russian region. In 18-24 age group, this proportion was 2.5 times higher (8,6\%). The main reasons for possible relocation were primarily related to the desire to solve socio-economic problems and get an education: the first place took the reason «due to work» (41.6\%), which was the most important across all ages, the second most popular reason was «the desire to improve the financial situation» (38.6\%), the third one was «due to study» (15.8\%). In 2013-2014, among those who actually left the republic, $45 \%$ of people were at ages 15-29 (Khilazheva, 2015). In recent years, about $25 \%$ of graduates are leaving the republic. However, the situation is worse in periphery, for example, in Uchalinsky district in 2010-2015, from 17.5 to $22 \%$ of graduates entered higher education institutions of the republic, while $47 \%$ to $55 \%$ chose to study in other regions (RBC research 2017). The rural districts in periphery of the republic also demonstrated higher shares of people who were employed in shift work both in Ufa and in other places outside the republic (Khilazheva 2019).

In migration literature (Khilazheva 2017; Khilazheva et al. 2017; Ataeva, Ulyaeva 2018; Valiahmetov et al 2018) we can find that all regions, which we discussed earlier in our analysis, are mentioned among the main destinations of permanent migrants from Bashkortostan. The Bashkortostan's neighbor regions also have huge Bashkir diaspora, which preserve ethnic identity from assimilation and may preserve social ties.

Thus, moving to another region, people retain connections with parents, relatives and friends in their home regions. Being a temporary by the nature, labor migration and holiday trips also fosters family members to stay connected during their separation.

From the economic standpoint, the Republic of Bashkortostan has the highest goods turnover with the Volga Federal District (115.1 billion rubles or 33,7\% in 2016), the Central Federal District (92.4 billion rubles, 27,1\%) and the Ural Federal District (61.2 billion rubles, 17,9\%). Among the regions that have close trade and economic cooperation with the republic, we should mention the Chelyabinsk oblast (36.4 billion rubles, 10,6\%), the Republic of Tatarstan (34.3 billion rubles, 10\%), Moscow (30.5 billion rubles, 8,9\%), the Moscow region (23.4 billion rubles, $6,8 \%$ ) and the Orenburg oblast (17.5 billion rubles, 5,1\%) (Interregional cooperation, 2020). Zakirov (2016) illustrates the cooperation in South Urals, providing the example of pyrometallurgical cycle of non-ferrous metals. First, copper and zinc concentrates are produced in Uchaly, Sibay and Buribay at the mining and processing enterprises with the total capacity of the processing plants of 6.7 million tons of ore per year. Then the production is conveyed to the Chelyabinsk, Orenburg and Sverdlovsk oblast for smelting pure metal at the copper and zinc smelters (Zakirov 2016).

According to different classifications, the Republic of Bashkortostan is part of the Ural Economic Region, the Volga Federal District and the Volga-Ural Macroregion. As we found, communicational ties between the republic and the first-order neighbor regions are much more solid than with higher-order neighbors. Being surrounded by the regions of the Ural Economic Region, the republic tends to be mostly a part of this group, however the republic has close social ties with Moscow, St. Petersburg and Krasnodar regions as well. In this regard, the case of a centrally located region has its own limitations. That is why further research is necessary to build a communication matrix for all regions, and eventually form cultural clusters for a better understanding of the spatial diversity of our country, and propose additional to demographic and economic criteria for regional classification. We would also be able to test the hypothesis that border countries have a bigger impact on Russian border regions, compared to the hinterland. Using individual level data may provide another insight on the migration ties between relatives in further research.

Being an alternative digital source of human behavior, cell phone data demonstrates communicational ties both as a result and a trigger of migration. While social media services allows us to build the friendship network, the cell phone data, besides this, identifies the directions of the conversations and thus may shed light on the economic and social influence and interaction. In our study, we succeed to identify calls between residents of the Republic Bashkortostan and other regions as well as between those who stayed in the republic and moved outside the region for some reason.

\section{CONCLUSION}

Overall, the people of the Republic of Bashkortostan have close connections with those who live in neighboring regions that underscores our first hypothesis. Economic relations and moved family members (including those who went to get education or work) are probably the main factors that could explain the pattern. Comparing the regional composition of the Ural Economic Region, the Volga Federal District and Volga-Ural Macro Region, we can prove that the population of the republic has bonded more with Ural regions. We reaffirm the validity of the Soviet economic grid, which considers the republic as part of the Ural Economic Region.

The Republic of Tatarstan is more economically developed than the Republic of Bashkortostan and more attractive for internal migrants. In addition, a quarter of the population of the Republic of Bashkortostan is Tatars. All of this led us to our second hypothesis in which we had supposed that the Republic of Bashkortostan has the closest connection with the Republic ofTatarstan. However, the latter was not emphasized in separate cluster (whereas Chelyabinsk oblast was) but in group with Orenburg and Sverdlovsk oblast. Unfortunately, we cannot split data on Moscow and Moscow region, which combined has stronger tie with the Republic of Bashkortostan than the Republic of Tatarstan solely. All of this makes it difficult to reject the second hypothesis and clearly confirm the third one, which implies the central role of the Russian capital in social communication.

Our paper is intended to stimulate further research at the intersection of international and regional relations, cultural studies, demography and economics. We are going to propose a further assessment of the interconnections and relationships between all Russian regions, to assist with an evidence based socio-economic zoning grid for effective country management, which in turn would lead to balanced spatial development, strengthening the interregional collaboration in infrastructure, investments and social policy. At this stage the results of this study can be utilized by researchers and Bashkir government to explore spatial interaction patterns between regions 
and may help to guide transportation planning and other potential applications, e.g. infrastructure construction projects.

Our research relied on voice traffic data of the cell phone operator. Increasing the availability of the Internet and widespread of the Social Media will lead to further shift of mobile voice communication into Internet space (for example, voice and text messages, voice and video calls on Skype, WhatsApp, etc.), that cannot give any information about directions of the calls. That is why we think that the current decade may become the last one, when researchers can estimate the social ties according to the voice traffic.

\section{REFERENCES}

Ataeva A.G. and Ulyaeva A.G. (2018). Modern trends and factors of inter-regional migration of youth in Russia. Vestnik Tomskogo gosudarstvennogo universiteta. Ekonomika - Tomsk State University Journal of Economics, 44, 38-57 (in Russian).

Distribution of internal Russian labor migrants by the subjects of the Russian Federation from which they leave (2020). Rosstat. Available online at: http://www.gks.ru/free_doc/new_site/population/trud/migrac/tab1_2018.xls [Accessed 22 June 2020] (in Russian).

Duration of residence of the population in the place of permanent residence. Volume 8. (in Russian). Available at: https://www.gks.ru/ free_doc/new_site/perepis2010/croc/perepis_itogi1612.htm [Accessed 14 May 2020].

Gao S., Liu Y., Wang Y. and Ma X. (2013). Discovering Spatial Interaction Communities from Mobile Phone Data. Transactions in GIS, 17, 463-481.

Inferring migrations, traditional methods and new approaches based on mobile phone, social media, and other big data. Feasibility study on inferring (labour) mobility and migration in the European Union from big data and social media data (2016). Wi'sniowski, Arkadiusz; Tatem, Andrew J; Abel, Guy J; Zagheni, Emilio; Weber, Ingmar; Sorichetta, Alessandro; Hughes, Christina, 40.

Khilazheva G.F. (2015). Migration behavior of residents of the Republic of Bashkortostan (analysis of sociological data (in Russian). Vestnik Akademii nauk RB, 20, 75-85.

Khilazheva G.F., Shamsutdinova N.K., Utyasheva I.B., Prudnikov V.B., Adigamova O.F. and Yagafarova D.G. (2017). Migration outflow from Bashkortostan in the context of redistribution of the human capital (in Russian). Bulletin USPTU, Science, education, economy, Series Economy, 4 (22), 165-173.

Khilazheva G.F. (2017). Participation of the people of Bashkortostan in the temporary labour migration. Problemy vostokovedeniya, 3 (77), 18-23 (in Russian).

Khilazheva G.F. (2019). The participation of residents of Russian regions in the temporary labor migration (on the example of Republic of Bashkortostan) (in Russian) // Budushchee sfery truda: global'nye vyzovy i regional'noe razvitie: sbornik statej Mezhdunarodnogo foruma «Budushchee sfery truda: dostojnyj trud dlya vsekh» (g. Ufa, 4-5 fevralya 2019 g.) / pod red. G.R. Bajmurzinoj, R.M. Valiahmetova. - Ufa: Mir Pechati, 425-429.

Makhrova A.G., Kirillov P.L. and Bochkarev A.N. (2017). Commuting of the population in the Moscow agglomeration: Estimating commuting flows using mobile operator data // Regional Research of Russia, 7(1), 36-44.

Interregional cooperation of the RB (2020). Gosudarstvennyj komitet Respubliki Bashkortostan po vneshneekonomicheskim svyazyam. Available online at: https://foreign.bashkortostan.ru/activity/419/ [Accessed 17 May 2020] (in Russian).

Population migration by flows (2020). Bashkortostanstat. Available online at: https://bashstat.gks.ru/storage/mediabank/\%D0\%9C\%D0 \%98\%D0\%93\%D0\%A0\%D0\%90\%D0\%A6\%D0\%98\%D0\%AF\%20\%D0\%9D\%D0\%90\%D0\%A1\%D0\%95\%D0\%9B\%D0\%95\%D0\%9D\%D0\%98\% D0\%AF\%20\%D0\%9F\%D0\%9E\%20\%D0\%9F\%D0\%9E\%D0\%A2\%D0\%9E\%D0\%9A\%D0\%90\%D0\%9C.pdf [Accessed 14 May 2020] (in Russian).

Population of Russia 2016 (2018). Twenty-fourth annual population report. Ed.: S.V. Zakharov. Moscow, HSE Publishing House, 448 (in Russian).

RBC research: what caused migration from Bashkiria (2017). RBC. Available at: https://www.rbc.ru/ufa/27/04/2017/5901b0de9a79474e ef6eb833 [Accessed 14 May 2020] (in Russian).

Russian regions: economic crisis and modernization problems (2011). Ed.: Grigoriev L.M., Zubarevich N.V., Khasaev G R. Moscow, Nauka, 349 (in Russian).

Volume 8. Duration of residence of the population in the place of permanent residence (in Russian). Available at: https://www.gks.ru/ free_doc/new_site/perepis2010/croc/perepis_itogi1612.htm [Accessed 14 May 2020].

Valiahmetov R.M., Bajmurzina G.R., Turakaev M.S. and Aitov S.G. (2018). Labor Migration as a Factor of Human Development in the Republic of Bashkortostan (in Russian) // Ekonomika i upravlenie: nauchno-prakticheskij zhurnal. 6, 147-156.

Virtual population of Russia (2020). Available at: http://webcensus.ru/ [Accessed 14 March 2020] (in Russian).

Yumaguzin V.V. and Vinnik M. V. (2019). Surnames in modern Russia. Annals of Human Biology, 46 (6), 475-490.

Yumaguzin V. V. (2017). Possibilities of studying pendulum migration based on mobile operators' data (on the example of Ufa) (in Russian) // Demoscope Weekly. № 727 - 728. Available at: http://www.demoscope.ru/weekly/2017/0727/analit01.php [Accessed 15 June 2020].

Zakirov I.V. (2016). Natural Resource Potential as a Factor of Development of Foreign Economic Relations of the Region (on the Example of the Republic of Bashkortostan). Izvestiya Irkutskogo gosudarstvennogo universiteta. Seriya: Nauki o Zemle, 16, $42-54$ (in Russian).

Zamyatina N. and Yashunskij A. (2018). Virtual geography of virtual population (in Russian). Monitoring Obshchestvennogo Mneniya: ekonomicheskie i Sotsialnye Peremeny. 143(1), 117-137.

Zubarev A. E. and Perevoznikova M. V. (2015). Review of the market of cellular communication services in Russia (in Russian). Bulletin of the Pacific State University, 3(36), 159-166. 
APPENDIX

The list of the used Russian regions

\begin{tabular}{|c|c|}
\hline Label & Region \\
\hline ABK & Republic of Khakassia \\
\hline ANR & Chukotka AD \\
\hline $\mathrm{ARH}$ & $\begin{array}{c}\text { Arkhangelsk oblast, } \\
\text { Nenets AD }\end{array}$ \\
\hline AST & Astrakhan oblast \\
\hline BAR & Altai krai \\
\hline BGK & Amur oblast \\
\hline BIR & Jewish AO \\
\hline BLG & Belgorod oblast \\
\hline BRN & Bryansk oblast \\
\hline BUR & Republic of Buryatia \\
\hline $\mathrm{CHB}$ & Chuvash Republic \\
\hline $\mathrm{CHL}$ & Chelyabinsk oblast \\
\hline $\mathrm{CHT}$ & Zabaykalsky krai \\
\hline EKT & Sverdlovsk oblast \\
\hline EST & Republic of Kalmykia \\
\hline GAL & Altai Republic \\
\hline GRZ & Chechen Republic \\
\hline HMS & Khanty-Mansi AD \\
\hline IGK & Udmurt Republic \\
\hline $\mathrm{IKO}$ & Mari El Republic \\
\hline IRK & Irkutsk oblast \\
\hline IVN & Ivanovo oblast \\
\hline KAL & Kaliningrad oblast \\
\hline $\mathrm{KCH}$ & $\begin{array}{c}\text { Karachay-Cherkess } \\
\text { Republic }\end{array}$ \\
\hline KIR & Kirov oblast \\
\hline KLG & Kaluga oblast \\
\hline KMR & Kemerovo oblast \\
\hline KRD & Krasnodar krai \\
\hline KRG & Kurgan oblast \\
\hline KRL & Republic of Karelia \\
\hline KRS & Krasnoyarsk krai \\
\hline KSK & Khabarovsk krai \\
\hline KSM & Kostroma oblast \\
\hline KUR & Kursk oblast \\
\hline
\end{tabular}

\begin{tabular}{|c|c|}
\hline Label & Region \\
\hline KZL & Tyva Republic \\
\hline KZN & Republic of Tatarstan \\
\hline LPK & Lipetsk oblast \\
\hline MAH & Republic of Dagestan \\
\hline MGD & Magadan oblast \\
\hline MSK & Moscow, Moscow oblast \\
\hline MUR & Murmansk oblast \\
\hline NAL & $\begin{array}{l}\text { Kabardino-Balkar } \\
\text { Republic }\end{array}$ \\
\hline NNG & Nizhni Novgorod oblast \\
\hline NSK & Novosibirsk oblast \\
\hline NZR & Republic of Ingushetia \\
\hline OMS & Omsk oblast \\
\hline ORB & Orenburg oblast \\
\hline $\mathrm{ORL}$ & Oryol oblast \\
\hline PNZ & Penza oblast \\
\hline PPK & Kamchatka krai \\
\hline PRM & Perm krai \\
\hline PSK & Pskov oblast \\
\hline RND & Rostov oblast \\
\hline RZN & Ryazan oblast \\
\hline SAM & Samara oblast \\
\hline SKH & Sakhalin oblast \\
\hline SML & Smolensk oblast \\
\hline SPB & $\begin{array}{c}\text { St. Petersburg, Leningrad } \\
\text { oblast }\end{array}$ \\
\hline SRN & Republic of Mordovia \\
\hline SRT & Saratov oblast \\
\hline STK & Komi Republic \\
\hline STV & Stavropol krai \\
\hline $\mathrm{TMB}$ & Tambov oblast \\
\hline TMS & Tomsk oblast \\
\hline TUL & Tula oblast \\
\hline TUM & Tyumen oblast \\
\hline TVR & Tver oblast \\
\hline UFA & $\begin{array}{c}\text { Republic of } \\
\text { Bashkortostan }\end{array}$ \\
\hline
\end{tabular}

\begin{tabular}{|c|c|}
\hline Label & Region \\
\hline ULN & Ulyanovsk oblast \\
\hline VLA & Primorsky krai \\
\hline VLD & Vladimir oblast \\
\hline VLG & Volgograd oblast \\
\hline VLK & Republic of North Ossetia \\
\hline VNG & Novgorod oblast \\
\hline VOL & Vologda oblast \\
\hline VRN & Voronezh oblast \\
\hline YAK & Republic of Sakha \\
\hline YAM & Yamalo-Nenets AD \\
\hline YRL & Yaroslavl oblast \\
\hline
\end{tabular}

